\section{Australian Journal of \\ Crop Science}

AJCS 15(01):82-87 (2021)

doi: 10.21475/ajcs.21.15.01.2805

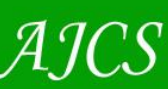

ISSN:1835-2707

\title{
Nitric oxide as a way to mitigate copper (Cu) toxicity in the emergence and initial growth of maize seedling (Zea mays L.)
}

\author{
Ana Ecidia de Araújo Brito ${ }^{1 *}$, Gerson Diego Pamplona de Albuquerque ${ }^{1}$, Juscelino Gonçalves Palheta ${ }^{1}$, \\ Jessica Suellen Silva Teixeira ${ }^{1}$, Diana Jhulia Palheta de Sousa ${ }^{1}$, Keila Beatriz Silva Teixeira ${ }^{1}$, Glauco André \\ dos Santos Nogueira ${ }^{1}$, Cândido Ferreira de Oliveira Neto ${ }^{1}$, Ismael de Jesus Matos Viégas ${ }^{2}$, Ricardo \\ Shigueru Okumura ${ }^{3}$
}

\author{
${ }^{1}$ Agricultural Sciences Institute, Federal Rural University of Amazônia, CEP: 66077-530, Belém, Pará, Brazil \\ ${ }^{2}$ Federal Rural University of Amazônia, Capanema Campus, Tv. Santa Cruz, 470 - Campinho, PA \\ ${ }^{3}$ Federal Rural University of Amazônia, Parauapebas Campus, CEP: 68515-000, endereço: PA-275 s / n \\ Zona Rural, Parauapebas, Pará, Brazil
}

\section{*Corresponding author: ecidiabrito@hotmail.com}

\begin{abstract}
The aim of this study is to assess the effect of sodium nitroprusside-NPS (nitric oxide donor) on the emergence and initial growth of maize seedlings (Zea mays L.) subjected to different copper concentrations. The study followed a completely randomized design at $4 \times 3$ factorial arrangement, with 12 treatments and 8 repetitions, totally 96 trays with 25 seedlings per repetition. Seedlings were soaked in sodium nitroprusside (SNP) solution ( 0.75 and $150 \mu \mathrm{M}$ - donor), sodium ferrocyanide (SF) (0.75 and $150 \mu \mathrm{M}$ compensator) and deionized water (control) on Germitest paper for 48 hours. Next, they were placed on sand saturated with $\mathrm{CuSO}_{4} .5 \mathrm{H}_{2} \mathrm{O}$ at concentrations of 0,100 and $200 \mu \mathrm{M}$. The results showed that SNP doses were not capable of mitigating copper toxicity in seedling emergence, influencing emergence speed coefficient and prolonging the mean emergence time of plants subjected to copper concentrations of $100 \mu \mathrm{M}$ and $200 \mu \mathrm{M}$. Copper concentrations rose the number of abnormal seedlings and had negative influence on plant biometrics and biomass. Copper concentration of $200 \mu \mathrm{M}$ increased proline content in the roots. NPS and sodium ferrocyanide application had effect on emergence speed index, shoot and root dry mass and on proline content in the shoot and roots. This outcome highlights that such effects were caused by treatments related to release of cyanide found in sodium nitroprusside (SNP), rather than to nitric oxide (NO).
\end{abstract}

Keywords: seedlings; toxicity by metal; micronutrient.

Abbreviations: NO_Nitric oxide; RL_Root length; TL_Total length; SL_Shoot length; SDM_Shoot dry mass; RDM_Root dry mass; CRD_Completely randomized design; ESI_Emergence speed index; MET_Mean emergence time; ESC_Emergence Speed Coefficient; SNP_Sodium nitroprusside; SF_Sodium Ferrocyanide.

Introduction

The exploration of minerals and metals can change the natural contents of heavy metals in the environment. Mining practices generate waste that accounts for significant risk by adding its toxicity to the soil, water, plants and living organisms (Cunha, 2017).

Maize is an essential product for the Brazilian agriculture. It is grown in all regions, countrywide, in more than 2 million farms. This culture underwent changes in the last decades, with emphasis on its reduction as subsistence culture for small farmers and on its role in the efficient commercial agriculture sector due to geographical production and temporal displacement (Contini, 2019).

Copper $(\mathrm{Cu})$ is a micronutrient essential for plants due its participation in plant metabolism and because it is a structural part of some enzymes (Gautam and Srivastava, 2016). High copper concentrations damage living beings. It has toxic effect on plant tissue and induces shortage of other basic nutrients because of antagonistic relationships (Taiz et al., 2017).

Plants grown in soils recording high copper content undergo biochemical stress, as well as drop in photosynthetic and respiration rates, which results in shorter roots and shoots, smaller root surface area and reduced biomass (Marques et al., 2018).

Nitric oxide (NO) is a signaling molecule involved in a wide range of responses to environmental stimuli. This molecule belongs to a family of reactive nitrogen species (RNS) because it has an unpaired electron. Therefore, it can interact with other reactive molecules such as Reactive Oxygen Species (ROS) and be eliminated from the cell. Besides, it can interact and change antioxidant enzymes and increase their activity (Arora et al., 2016; Salgado et al., 2017).

According to Santos (2009), the treatment with NO donor induced the activity of P-ATPase, V-ATPase and PPase, which 
proves the hypothesis of its participation in the modulation of proton pumps. Nitric oxide is a messenger molecule; thus, in most cases, it responds to stress because of its interaction with phytohormones (Fan et al., 2014; Du et al., 2015; Sanz et al., 2015).

Copper toxicity in the physiological and biochemical attributes of plants was reported in studies by Apodaca et al. (2017), Marques et al. (2018) and Noreen et al. (2018). Contamination by copper led to reduced shoot and root dry mass production since growth is the final expression of all processes.

Studies have shown that the application of exogenous NO, in the form of sodium nitroprusside-SNP, improves plant tolerance to heavy metal-induced stress (Wang et al., 2013). These studies pointed out that the protective effect of SNP derived from NO release.

However, according to Silva et al. (2018), these effects were similar to those caused by the treatment with sodium nitroprusside. They were also observed in treatments with inactive sodium nitroprusside and ferrocyanide. This outcome indicates that the observed effects were associated with cyanide release by sodium nitroprusside.

Thus, the aim of the present study was to assess the mitigating effect of sodium nitroprusside, which is nitric oxide donor, based on variables related to the emergence, biometrics, biomass and proline contents in the leaves and roots of hybrid maize (variety K9606 VIP3) seedlings subjected to different copper concentrations.

\section{Results and discussion}

There was interaction between sodium nitroprusside-SNP and copper concentrations in the following variables: emergence speed index (ESI), root length (RL), root dry mass (RDM) and shoot dry mass (SDM), as shown in Tables 1 and 2.

\section{Maize seedling emergence}

Sodium nitroprusside-SNP doses did not affect seedlings' emergence parameters, but treatments added with copper had isolated effect on them. The treatment with $0 \mu \mathrm{M}$ of copper recorded mean emergence of $82.11 \%$ in comparison to treatments with $100 \mu \mathrm{M}$ and $200 \mu \mathrm{M}$ of copper, which have recorded $0 \%$ seedling emergence. There was $100 \%$ reduction in the emergence of seedlings subjected to treatments with $100 \mu \mathrm{M}$ and $200 \mu \mathrm{M}$ of copper in comparison to the treatment with $0 \mu \mathrm{M}$ (Table 1).

The drastic effect of heavy metals on seed emergence can be related to reduced activity of $\alpha$ and $\beta$ amylases. This outcome compromises plant respiration and impairs growth in the embryonic and root axis (Pires et al., 2016). Therefore, the inhibition of these enzymes can point towards the toxicity mechanisms of sensitive plants exposed to these elements, which can work as indicators in contaminated environments given their fast response to damaging effects (Kong, 2013). Moreover, seedling emergence inhibition can be associated with reduced osmotic ability, with emergence medium potential and mainly with high copper concentrations (Ahsan et al., 2007).

\section{Emergence speed index - ESI}

The treatment with $0 \mu \mathrm{M}$ showed that some sodium nitroprusside-SNP doses mitigated copper toxicity effects in the treatment with $100 \mu \mathrm{M}$ of copper, but it did not happen in treatments with $200 \mu \mathrm{M}$ of copper. The highest mean (12.27\%) was recorded for the treatment with $150 \mu \mathrm{M}$ of SNP and $100 \mu \mathrm{M}$ of copper. This number was increased to $21.6 \%$, compared to the control. On the other hand, the lowest mean (8.21\%) was observed for the treatment with 0 $\mu \mathrm{M}$ of SNP and $200 \mu \mathrm{M}$ of copper compared to the control (0 $\mu \mathrm{M}$ of SNP and $200 \mu \mathrm{M}$ of copper), which recorded $18.7 \%$ reduction in comparison to the control.

ESI delay due to exposure to $\mathrm{Cu}$ may have resulted from reduced nitrogen availability on the embryonic axis. It happens because of protein synthesis inhibition caused by lower availability of amino acids in the tegument (Karmous et. al., 2012).

However, some authors argue that the effect of nitric oxide donors actually derive from the nitric oxide itself. SNP was used to overcome dormancy in Arabidopsis seeds. Nevertheless, the authors have found that the effect resulted from cyanide in SNP (Bethke et al., 2006). One of the possible effects of cyanide would be $\mathrm{O}_{2}$ availability for the oxidative pathway of pentose phosphate.

\section{Emergence speed coefficient (ESC) and Mean Emergence Time (MET)}

Sodium nitroprusside-SNP showed effect on emergence speed coefficient-ESC and copper had isolated effect on the treatment with copper concentration of $200 \mu \mathrm{M}$. The treatment with $0 \mu \mathrm{M}$ of copper recorded $34.33 \%$, on average, which concerns $20.1 \%$ reduction in comparison to the treatment with $0 \mu \mathrm{M}$ of copper (Table 1).

Variable mean emergence time-MET recorded longer mean emergence time in the treatment with copper concentration of $200 \mu \mathrm{M}$, which showed MET of $2.91 \%$, whereas the treatment with $0 \mu \mathrm{M}$ of copper recorded MET of $2.29 \%$, which regards $27.3 \%$ increase in comparison to the treatment with $0 \mu \mathrm{M}$ of copper (Table 1 ).

Germination delay can happen due to the protection role played by the tegument in seeds. It is capable of blocking and accumulating trace elements on its surface. Therefore, when the trace element is absorbed, it is deposited in the endosperm, which accounts for providing nutrients to the germination process; therefore, it can be translocated to the embryo (Sun and Luo, 2014).

According to Chaâbene et al. (2018), the beginning of root emergence requires high water content in the seeds, so that the metabolic activity necessary for germination can take place. Yet, seeds response to this hydration changes depends on their ability to control inner water level. Seed germination changes can be explained by changes in water absorption. Actually, cupric ions have toxic effect because they create an external osmotic potential to stop water capture in a way similar to that carried out by ions $\mathrm{Na}^{+}$and $\mathrm{Cl}^{-}$.

\section{Abnormal seedlings}

Sodium nitroprusside-SNP doses did not mitigate the toxicity effect of copper in comparison to abnormal seedlings. However, there was isolated effect of copper concentrations in the treatments. Treatments with copper concentrations of $100 \mu \mathrm{M}$ and $200 \mu \mathrm{M}$ recorded means of $99.32 \%$ and $99.75 \%$, respectively, in comparison to the treatment with $0 \mu \mathrm{M}$ of copper, which recorded mean of $16.01 \%$. This outcome 
Table 1. Total length (TL), shoot length (SL), proline in root (PR), emergence, emergence speed coefficient (ESC), abnormal seedlings, mean emergence time (MET) of maize seedlings treated with sodium nitroprusside (SNP), nitric oxide donor, sodium ferrocyanide (SFC), compensator and exposed to toxicity caused by copper.

\begin{tabular}{|c|c|c|c|c|c|c|c|}
\hline Copper & TL & SDL & Proline in the root & Emergence & ESC & Abnormal seedlings & MET \\
\hline$(\mu \mathrm{M})$ & ------ $(\mathrm{cm})$------ & & $\left(\mu \mathrm{M}\right.$ Pro $\left.\mathrm{g}^{-1} \mathrm{MS}\right)$ & \multicolumn{3}{|c|}{--------------------------(\%)------------------------- } & (day) \\
\hline 0 & $28.07 \pm 2.00 \mathrm{a}$ & $5.72 \pm 0.78 a$ & $1.64 \pm 0.18 c$ & $82.11 \pm 10.97 \mathrm{a}$ & $42.96 \pm 4.22 \mathrm{a}$ & $16.01 \pm 11.08 b$ & $2.29 \pm 0.28 c$ \\
\hline 100 & $6.29 \pm 0.52 b$ & $3.52 \pm 0.45 b$ & $4.33 \pm 0.32 b$ & $0.00 \pm 0.00 \mathrm{~b}$ & $40.32 \pm 5.15 a$ & $99.32 \pm 1.48 a$ & $2.51 \pm 0.28 b$ \\
\hline 200 & $4.58 \pm 0.31 c$ & $2.53 \pm 0.16 c$ & $5.16 \pm 0.23 a$ & $0.00 \pm 0.00 \mathrm{~b}$ & $34.33 \pm 1.97 b$ & $99.75 \pm 0.98 a$ & $2.91 \pm 0.16 a$ \\
\hline
\end{tabular}

Table 2. Root length (RL), emergence speed index (ESI), shoot dry mass (SDM) and root dry mass (RDM) of maize seedlings treated with sodium nitroprusside (SNP), nitric oxide donor, sodium ferrocyanide (SFC), compensator and exposed to toxicity caused by copper.

\begin{tabular}{|c|c|c|c|c|c|}
\hline \multirow{2}{*}{ Treatment } & \multirow{2}{*}{$\begin{array}{l}\text { Copper } \\
(\mu \mathrm{M}) \\
\end{array}$} & \multirow{2}{*}{$\begin{array}{l}\mathrm{RL} \\
(\mathrm{cm})\end{array}$} & \multirow{2}{*}{ - ESI } & \multirow{2}{*}{\multicolumn{2}{|c|}{$\begin{array}{lr}\text { SDM } & \text { RDM } \\
-----\left(\text { mg seedling }^{-1}\right) \text {----- } \\
\end{array}$}} \\
\hline & & & & & \\
\hline & 0 & $22.77 \pm 1.19 \mathrm{ABa}$ & $10.10 \pm 0.61 \mathrm{Ba}$ & $17.05 \pm 2.61 \mathrm{Aab}$ & $68.85 \pm 26.07 \mathrm{Aa}$ \\
\hline \multirow[t]{3}{*}{ Water } & 100 & $3.45 \pm 0.47 \mathrm{Ab}$ & $10.42 \pm 0.75 \mathrm{ABa}$ & $19.30 \pm 2.64 \mathrm{Aa}$ & $27.00 \pm 3.51 \mathrm{Ab}$ \\
\hline & 200 & $1.90 \pm 0.16 \mathrm{Ac}$ & $9.10 \pm 0.95 \mathrm{Aa}$ & $14.25 \pm 2.64 \mathrm{Ab}$ & $33.10 \pm 11.85 \mathrm{Ab}$ \\
\hline & 0 & $21.66 \pm 0.98 \mathrm{BCa}$ & $11.08 \pm 0.77 \mathrm{ABa}$ & $18.10 \pm 1.72 \mathrm{Aa}$ & $65.50 \pm 21.65 \mathrm{Aa}$ \\
\hline \multirow[t]{3}{*}{ SNP $(0 \mu \mathrm{M})+\operatorname{SFC}(150 \mu \mathrm{M})$} & 100 & $2.72 \pm 0.21 \mathrm{Bb}$ & $10.04 \pm 0.89 \mathrm{ABab}$ & $17.00 \pm 3.40 \mathrm{ABab}$ & $30.30 \pm 7.23 \mathrm{Ab}$ \\
\hline & 200 & $1.98 \pm 0.15 \mathrm{Ac}$ & $8.21 \pm 0.61 \mathrm{Ab}$ & $14.10 \pm 2.40 \mathrm{Ab}$ & $30.05 \pm 4.03 \mathrm{ABb}$ \\
\hline & 0 & $20.75 \pm 1.24 \mathrm{Ca}$ & $11.68 \pm 2.31 \mathrm{ABa}$ & $19.40 \pm 1.86 \mathrm{Aa}$ & $68.95 \pm 21.93 \mathrm{Aa}$ \\
\hline \multirow[t]{3}{*}{ SNP $(75 \mu \mathrm{M})+\operatorname{SFC}(75 \mu \mathrm{M})$} & 100 & $2.41 \pm 0.19 \mathrm{Cb}$ & $9.37 \pm 0.38 \mathrm{Ba}$ & $17.60 \pm 2.69 \mathrm{ABab}$ & $34.45 \pm 4.67 \mathrm{Ab}$ \\
\hline & 200 & $2.08 \pm 0.15 \mathrm{Ac}$ & $8.40 \pm 0.21 \mathrm{Ab}$ & $15.30 \pm 2.10 \mathrm{Ab}$ & $27.00 \pm 3.81 \mathrm{ABC}$ \\
\hline & 0 & $23.80 \pm 1.84 \mathrm{Aa}$ & $11.63 \pm 0.32 \mathrm{Aa}$ & $20.10 \pm 2.93 \mathrm{Aa}$ & $83.35 \pm 32.98 \mathrm{Aa}$ \\
\hline \multirow[t]{2}{*}{ SNP $(150 \mu \mathrm{M})+$ SFC $(0 \mu \mathrm{M})$} & 100 & $2.80 \pm 0.27 \mathrm{Bb}$ & $12.27 \pm 2.56 \mathrm{Aa}$ & $14.65 \pm 3.82 \mathrm{Bb}$ & $30.30 \pm 4.19 \mathrm{Ab}$ \\
\hline & 200 & $2.04 \pm 0.09 \mathrm{Ac}$ & $9.03 \pm 0.85 \mathrm{Ab}$ & $14.40 \pm 2.07 \mathrm{Ab}$ & $24.45 \pm 4.29 \mathrm{BC}$ \\
\hline
\end{tabular}

Columns with different capital letters between treatments (water, SNP $(0 \mu \mathrm{M})+\operatorname{SFC}(150 \mu \mathrm{M})$, SNP $(75 \mu \mathrm{M})+\operatorname{SFC}(75 \mu \mathrm{M})$, SNP $(150 \mu \mathrm{M})+\operatorname{SFC}(0 \mu \mathrm{M})$ under the same copper concentration) and lowercase letters between copper concentrations $(0,100$ and $200 \mu \mathrm{M}$ under the same treatment) point out significant differences in the Tukey test at $5 \%$ probability level. Described values correspond to the means of five repetitions and SD.

Table 3. Proline in the shoot and proline in the root of maize seedlings treated with sodium nitroprusside (SNP), nitric oxide donor, sodium ferrocyanide (SFC), and compensators and exposed to toxicity caused by copper.

\begin{tabular}{|c|c|c|}
\hline \multirow{2}{*}{ Treatment } & \multicolumn{2}{|c|}{ Proline in the shoot Proline in the root } \\
\hline & ---- $\left(\mu \mathrm{M}\right.$ Pro g ${ }^{-1} \mathrm{M}$ & S)------- \\
\hline Water & $3.51 \pm 0.19 a$ & $3.01 \pm 0.49 b$ \\
\hline SNP $(0 \mu \mathrm{M})+$ SFC $(150 \mu \mathrm{M})$ & $3.48 \pm 0.19 a$ & $4.87 \pm 0.64 a$ \\
\hline $\operatorname{SNP}(75 \mu \mathrm{M})+\operatorname{SFC}(75 \mu \mathrm{M})$ & $2.92 \pm 0.15 b$ & $3.84 \pm 0.44 a$ \\
\hline $\operatorname{SNP}(150 \mu \mathrm{M})+\operatorname{SFC}(0 \mu \mathrm{M})$ & $2.95 \pm 0.18 b$ & $2.85 \pm 0.38 b$ \\
\hline
\end{tabular}

indicates $520.4 \%$ and $523 \%$ increase in treatments with copper concentrations of $100 \mu \mathrm{M}$ and $200 \mu \mathrm{M}$, respectively, compared to $0 \mu \mathrm{M}$ copper (Table 1 ).

The phytotoxic effect of copper leads to disturbance in cell development and differentiation, generating abnormal changes and reduces the rate of normal seedlings at germination (Pires et al., 2016). This effect evolves from membrane degeneration, reduced growth and development rate, lower uniformity and higher sensitivity to adversities, emergence reduction in the field and formation of abnormal seedlings, to loss of germination power (Marcos Filho, 2015).

\section{Root Length (RL)}

Variable showed that sodium nitroprusside-SNP only affected the treatment with $0 \mu \mathrm{M}$ of copper, which recorded the highest mean root length $(23.8 \mathrm{~cm})$ in the treatment with $150 \mu \mathrm{M}$ of SNP and $0 \mu \mathrm{M}$ copper $-4.6 \%$ increase in comparison to the control. The lowest mean root length $(1.9 \mathrm{~cm})$ was observed for the treatment with copper concentration of $200 \mu \mathrm{M}$, which presented $91.7 \%$ root length reduction in comparison to the control treatment (Table 2). Enzyme activation block, reduced straight blocking of cell division and its influence on mitosis formation can explain the reduced root growth. Repression of protein synthesis and DNA replication can also block cell division (Moosavi et al., 2012).

NO action boosted root growth in the treatment with copper concentration of $0 \mu \mathrm{M}$. NO can be involved in the auxin signaling pathway, since it increases calcium level and activates protein kinases, which participates in the development of adventitious and lateral roots (Lanteri et al., 2006).

According to Ya'Acov and Haramaty (1996), NO acts in the phospholipid bilayer membrane and increases its fluidity. It can also act in relaxing cell wall and contribute to plant growth.

Based on Sarath et al. (2006), cyanide likely induces nitric oxide production at seed germination, which in its turn, aims proteins that favor cell elongation (root emergence) and growth (coleoptile extension).

The excess of this metal affects the root system, as well as shoot growth, and it induces disturbances in proteins and inhibits cell elongation due to increased plasmatic membrane permeability and cell wall lignification, which leads to plants with dwarfism symptoms (Yruela, 2009). 


\section{Shoot length (SL) and Total Length (TL)}

Sodium nitroprusside-SNP doses did not influence shoot length (SL), but there was isolated effect of different copper concentrations. Copper concentration of $200 \mu \mathrm{M}$ led to mean shoot length of $2.53 \mathrm{~cm}$, which concerns $55.8 \%$ reduction in comparison to the treatment with $0 \mu \mathrm{M}$ of copper, which recorded mean shoot length of $5.72 \mathrm{~cm}$ (Table $1)$.

There was no effect of sodium nitroprusside-SNP on total length-TL, but there was isolated effect of copper. The treatment with copper concentration of $200 \mu \mathrm{M}$ presented mean total length of $4.58 \mathrm{~cm}$, which regards $83.7 \%$ reduction in comparison to the treatment with $0 \mu \mathrm{M}$ of copper. It presented mean total length of $28.07 \mathrm{~cm}$ (Table 1 ).

Copper excess can promote physiological, biochemical and morphoanatomical disturbances that can inhibit plant development (Gautam and Srivastava, 2016).

Besides reducing cell division, copper excess inhibits the activity of enzymes $\alpha$-amylase and invertase, as well as affects nutrient accumulation mobilization and water absorption by the tissue (Sethy and Ghosh, 2013).

\section{Root dry mass (RDM) and shoot dry mass (SDM)}

The effect of sodium nitroprusside-SNP did not influence root dry mass-RDM in the treatment with $0 \mu \mathrm{M}$ of copper. It showed that copper concentration of $200 \mu \mathrm{M}$ accounted for reduced results in this variable.

The treatment with the following doses: $150 \mu \mathrm{M}$ of SNP and $200 \mu \mathrm{M}$ of copper, presented mean root dry mass of 24.45 $\mathrm{mg}$; whereas, the control treatment recorded mean of 68.85 $\mathrm{mg}$, which accounts for $64.5 \%$ reduction. On the other hand, the treatment with doses of $150 \mu \mathrm{M}$ of SNP and $0 \mu \mathrm{M}$ of copper showed mean root dry mass of $83.35 \mathrm{mg}$. It regards $21.1 \%$ increase in comparison to the control (Table 2).

There was sodium nitroprusside-SNP effect on shoot dry mass-SDM in the treatment with $0 \mu \mathrm{M}$ of copper. The treatment with dose of $150 \mu \mathrm{M}$ of SNP and $0 \mu \mathrm{M}$ of copper recorded mean shoot dry mass of $20.10 \mathrm{mg}$, which concerns $17.9 \%$ increase in comparison to the control treatment. It presented mean shoot dry mass of $17.05 \mathrm{mg}$. The treatment with $0 \mu \mathrm{M}$ of SNP and $200 \mu \mathrm{M}$ of copper showed the lowest mean $(14.10 \mathrm{mg})$, which is $17.3 \%$ reduction in comparison to the control (Table 2).

The phytotoxic effect of heavy metals depends on plant development stage. It can be featured by diminished total plant phytomass, shoot and root length, delayed development and lower chlorophyll concentration (Pinto, 2017).

Root length is a parameter widely used in bioassays applied to phytotoxicity (Simões et al., 2013). According to these authors, reduced mean length in lettuce can be related to lower cell division rates in the meristematic region, since this region accounts for root growth. This process influences root dry mass reduction.

\section{Proline content}

There was isolated effect of copper concentration in proline content in the roots. The treatment with copper concentration of $200 \mu \mathrm{M}$ recorded mean proline content in the roots of $5.16 \mu \mathrm{M}$ Pro $\mathrm{g}^{-1} \mathrm{MS}$, which means $214.68 \%$ increase compared to $0 \mu \mathrm{M}$ of copper, which presented mean proline content in the roots of $1.64 \mu \mathrm{M}$ Pro $\mathrm{g}^{-1} \mathrm{MS}$ (Table 1).

There was sodium nitroprusside-SNP effect on proline content in the shoot, which decreased in treatments with dose of 75 and $150 \mu \mathrm{M}$ of SNP. They recorded mean proline content in the shoot of 2.92 and $2.95 \mu \mathrm{M}$ Pro $^{-1} \mathrm{MS} ; 17.05 \%$ and $16.07 \%$ reduction, respectively; in comparison to the control (Table 3).

Sodium nitroprusside-SNP had isolated effect on the proline content in the roots. It meant increased rates in the treatment with $0 \mu \mathrm{M}$ dose of NPS, which presented mean proline content in the roots $\sim 4.87 \mu \mathrm{M}$ Pro $\mathrm{g}^{-1} \mathrm{MS}$, meaning $61.73 \%$ increase in proline content in the roots in comparison to the control treatment (Table 3).

Nitric oxide is related to auxin transport and higher levels of radical impairs in primary root growth (Fernández-Marcos et al., 2011). However, this radical plays a relevant role in the development of the apical meristem at appropriate levels.

Nowadays, most studies about the interaction between indole acetic acid-AIA and NO are concentrated in root responses; therefore, information about the shoot are scarce (Simontacchi et al., 2013). According to Fahad et al. (2015), NO can modulate the AIA level and control its degradation.

Proline can carry out different functions in response to abiotic stress in plants, such as osmoprotective response, with emphasis on the protection role of the membrane against damaging effects caused by the excess of heavy metals. Oftentimes, there are high contents of these substances under stress conditions (Gautam and Srivastava, 2016).

NO increases the activity of enzyme pyrroline-5-carboxylate synthase (P5CS), which participates in proline biosynthesis and inhibits the activity of enzyme proline dehydrogenase (PDH) that, in its turn, is involved in NO activity degradation (Fan et al., 2012).

NO in plants has antioxidant action and regulates the level and toxicity of reactive oxygen species (ROS), which are generated by different stress types (Sang et al., 2008). Apparently, NO rises the ascorbate levels and activates enzymes of the antioxidant system in cells (Zhang et al., 2008). The protective effect of the exogenous application of SNP has been attributed to the elimination of superoxide radicals (• O2-) and/or to the increased activity of antioxidant enzymes (Wang et al., 2010).

\section{Materials and Methods}

\section{Experiment conduction}

The experiment was carried out in the Laboratory of Top Plant Studies (EBPS) of the Agricultural Sciences Institute of Federal Rural University of Amazônia (UFRA). Seeds of hybrid maize K 9606 VIP3 were provided by the company SAAT SE \& Co. KGaA and used in the experiment.

\section{Seed treatment}

Seeds were soaked in solution with sodium nitroprusside $\mathrm{Na}_{2}\left[\mathrm{Fe}(\mathrm{CN})_{5} \mathrm{NO}\right] 2 \mathrm{H}_{2} \mathrm{O}(0.75$ and $150 \mu \mathrm{M})$, with nitric oxide donor, sodium ferrocyanide $\mathrm{Na}_{4} \mathrm{Fe}(\mathrm{CN})_{6}(0.75$ and $150 \mu \mathrm{M})$, as compensator, and deionized water (control), on Germitest paper for 48 hours.

Seeds were placed on trays filled with washed and autoclaved sand, dried in air circulating oven at $70^{\circ} \mathrm{C}$. The 
sand saturated with copper concentrations of $\mathrm{CuSO}_{4} \cdot 5 \mathrm{H}_{2} \mathrm{O}$ $(0,100$ and $200 \mu \mathrm{M})$ and deionized water (control) at $60 \%$ field capacity, 8-h photoperiod (8 hours of light and 16 hours of darkness) and temperature of $25^{\circ} \mathrm{C} \pm 2{ }^{\circ} \mathrm{C}$ (RAS).

\section{Analysis of emergence, biometrics, biomass and proline content}

The counting of emerged seedling was daily performed from $4^{\text {th }}$ to the $7^{\text {th }}$ day after experiment implementation. The emergence criteria were proposed by Brasil (2009). It led to the formation of seedlings presenting normal essential structures (primary root, coleoptile and plumule).

According to Silva and Nakagawa (1995), the emergence was expressed in percentages and the formulation expressed by Edmond and Drapala (1958) were used to calculate mean emergence time (MET). The formulation proposed by Kotowski (1926) was used to calculate the emergence speed coefficient. The emergence speed index was calculated through the formulation proposed by Maguire (1962).

Mean shoot length (MSL) and root system (RS) were measured at the end of the germination test. Eight (8) repetitions, with 15 seedlings from each treatment, were used in the experiment. Their measurements were carried out in the seventh day after sowing, with the aid of a millimeter ruler, results were expressed in $\mathrm{cm}$ seedling $^{-1}$ (Nakagawa, 1999).

Shoot dry mass (SDM) and root dry system (RDS) were calculated through the method based on circulating air oven at $70^{\circ} \mathrm{C}$ used to reach constant weight (Nakagawa, 1999). Proline concentrations were determined based on the methods described by Bates et al. (1973).

\section{Study design and statistical analysis}

The study followed a completely randomized design at $4 \times 3$ factorial arrangement. The 4 treatments consisted of (water, SNP $(0 \mu \mathrm{M})+$ SFC $(150 \mu \mathrm{M})$, SNP $(75 \mu \mathrm{M})+$ SFC $(75 \mu \mathrm{M})$, SNP $(150 \mu \mathrm{M})+\mathrm{SFC}(0 \mu \mathrm{M})$ at 3 different copper concentrations $(0,100$ and $200 \mu \mathrm{M})$, totally 12 treatments, with 8 repetitions; 96 trays filled with 25 seeds per repetition. Data were subjected to the analysis of variance (ANOVA) with Tukey test at $5 \%$ probability, carried out in the SISVAr software.

\section{Conclusion}

Sodium nitroprusside (SNP) concentrations and nitric oxide (NO) donor were not capable of mitigating copper toxicity in the emergence of maize seedlings belonging to variety K9606VIP3. They did not influence the emergence speed coefficient and prolonged the mean emergence time of seedlings subjected to treatments with copper concentrations of $100 \mu \mathrm{M}$ and $200 \mu \mathrm{M}$.

Copper concentrations of $100 \mu \mathrm{M}$ and $200 \mu \mathrm{M}$ raised the number of abnormal seedlings. It had negative influence on the biometrics and biomass of maize seedlings. The highest copper concentration $(200 \mu \mathrm{M})$ increased the proline content in the roots of maize seedlings, with emphasis on the osmoprotector role against abiotic stress caused by the excess of this metal.

Sodium nitroprusside, nitric oxide donor, and sodium ferrocyanide application showed effect on emergence speed index, shoot and root dry mass and on the proline content in the shoot and roots. This outcome indicates that such effects are caused by treatments that can be related to the release of cyanide found in sodium nitroprusside-SNP, rather than by nitric oxide. In-depth studies are necessary to reach better conclusions about the herein observed effects.

\section{Acknowledgement}

We are grateful to Capes - Coordenação de Aperfeiçoamento de Pessoal de Nível Superior, for granting the scholarships and for UFRA - Federal Rural University of Amazônia. EBPSBiodiversity Studies in Top Plants Team.

\section{References}

Ahsan N, Lee SH, Lee DG, Lee H, Lee SW, Bahk JD, Lee BH (2007) Physiological and protein profiles alternation of germinating rice seedlings exposed to acute cadmium toxicity. C R Biol. 330: 735-746.

Apodaca SA, Tan W, Dominguez O, Hernandez-Viezcas J, Peralta-Videa JR, Gardea-Torresdey, JL (2017) Physiological and biochemical effects of nanoparticulate copper, bulk copper, copper chloride, and kinetin in kidney bean (Phaseolus vulgaris) plants. Sci Total Environ. 599-600: 2085-2094.

Arora D, Jain P, Singh N, Kaur H, Bhatla SC (2016) Mechanisms of nitric oxide crosstalk with reactive oxygen species scavenging enzymes during abiotic stress tolerance in plants. Free Radical Res. 50: 291-303.

Bates LS, Waldren RPE, Teare ID (1973) Rapid determination of free proline for water-stress studies. Short communication. Plant Soil. 39: 205-207.

Bethke PC, Libourel IGL, Jones RL (2006) Nitric oxide reduces seed dormancy in Arabidopsis. J Exp Bot. 57: 517-526.

Brasil (2009) Ministério do Meio Ambiente. Resolução no 420, de 28 de dezembro de 2009. Diário Oficial da República Federativa do Brasil: Brasília, DF, 249. 81-84.

Chaâbene Z, Hakim IR, Rorat A, Elleuch A, Mejdoub H, Vandembulcke $F$ (2018) Copper toxicity on date palm (Phoenix dactylifera) seedlings tolerance: monitoring of related biomarkers. Environ Toxicol Chem. 37: 797-8006.

Contini E, Mota MM, Marra R, Borghi E, Miranda RA, Silva AF, Silva DD, Machado JRA, Cota LV, Costa RV, Mendes SM (2019) Milho: caracterização e desafios tecnológicos. Brasília: Embrapa - Desafios do Agronegócio Brasileiro NT2.

Cunha CSM (2017) Metais pesados em solos, plantas e qualidade da água em área de mineração fósforouranífera-CE. 2017. 168 f. Tese. Universidade Federal do Ceará.

Du ST, Liu Y, Zhang P, Liu HJ, Zhang XQ, Zhang RR (2015) Atmospheric application of trace amounts of nitric oxide enhances tolerance to salt stress and improves nutritional quality in spinach (Spinacia oleracea L.). Food Chem. 173: 905-911.

Edmond JB, Drapala WJ (1958) The effects of temperature, sand and soil, and acetone on germination of okra seed. J Am Soc Hortic Sci. 71: 428-434.

Fahad S, Hussain S, Matloob A, Khan FA, Khaliq A, Saud S, Faiq M (2015) Phytohormones and plant responses to salinity stress: a review. Plant Growth Regul. 75: 391-404.

Fan H, Du C, Xu Y, Wu X (2014) Exogenous nitric oxide improves chilling tolerance of chinese cabbage seedlings by affecting antioxidant enzymes in leaves. Hortic Environ Biote. 55: 159-165. 
Fan HF, Du CX, Guo SR (2012) Effect of nitric oxide on proline metabolism in cucumber seedlings under salinity stress. J Am Soc Hortic Sci. 137: 127-133.

Fernández-Marcos M, Sanz L, Lewis DR, Muday GK, Lorenzo O (2011) Nitric oxide causes root apical meristem defects and growth inhibition while reducing PINFORMED 1 (PIN1)-dependent acropetal auxin transport. Proc. Natl. Acad. Sci. U.S.A. 108: 18506-18511.

Gautam S, Srivastava N (2016) In vitro evaluation of excess copper affecting seedlings and their biochemical characteristics in Carthamus tinctorius L. (variety PBNS12). Physiol Mol Biol Pla. 1-9.

Karmous I, Khadija J, Chaoui A, Ferjano EE (2012) Proteolytic activities in Phaseolus vulgaris cotyledons under copper stress. Physiol Mol Biol Pla. 18: 337-343.

Kong IC (2013) Joint effects of heavy metal binary mixtures on seed germination, root and shoot growth, bacterial bioluminescence, and gene mutation. J Environ Sci. 25: 889-894.

Kotowski $F$ (1926) Temperature relations to germination of vegetable seeds. Proc Amer Hort Sci. 76: 23-1.

Lanteri ML, Pagnussat GC, Lamattina L (2006) Calcium and calciumdependent protien kinases are involved in nitric oxide-and auxin-induced adventitious root formation in cucumber. J Exper Bot. 57: 1341-1351.

Maguire JD (1962) Speed of germination and in selection and evaluation for seedlings emergence and vigor. Crop Sci. 2: 176-177.

Marcos Filho J (2015) Fisiologia de sementes de plantas cultivadas. Londrina. ABRATES, $659 \mathrm{p}$.

Marques DM, Silva AB, Mantovani JR, Pereira DS, Souza TC (2018) Growth and physiological responses of tree species (Hymenaea courbaril L., Peltophorum dubium (Spreng.) Taub. and Myroxylon peruiferum L. F.) exposed to different copper concentrations in the soil. Rev Árv. 42: 67-62.

Moosavi SA, Gharineh MH, Afshari RT, Ebrahimi A (2012) Effects of Some Heavy Metals on Seed Germination Characteristics of Canola (Barassica napus), Wheat (Triticum aestivum) and Safflower (Carthamus tinctorious) to Evaluate Phytoremediation Potential of These Crops. J Agr Sci. 4: 11-19.

Nakagawa J (1999) Testes de vigor baseados na avaliação de plântulas. In: Krzyzanowski FC, Vieira RD, França-Neto JB (ed.) Vigor de sementes: conceitos e testes, Londrina: ABRATES, p. 2:1- 2:21.

Noreen S, Akhter MS, Yaamin T, Arfan M (2018) The ameliorative effects of exogenously applied proline on physiological and biochemical parameters of wheat (Triticum aestivum L.) crop under copper stress condition. J Plant Interact. 13: 221-230.

Pinto FR (2017) Caracterização da acumulação e da tolerância ao stress induzido por $\mathrm{Cd}$ em plantas de espinafre (Spinacea oleracea L.). 2017. 257 f. Tese. Universidade de Lisboa.

Pires RMO, Souza GA, Cardoso AA, Dias DCFS, Borges EEL (2016) Action of nitric oxide in sesame seeds (Sesamum indicum L.) submitted to stress by cadmium. J. Seed Sci. 38: $22-29$

Salgado I, Oliveira HC, Gaspar M (2017) Plant nitric oxide signaling under environmental stresses. Mechanism of Plant Hormone Signaling Under Stress: A Functional Genomic Frontier.
Sang J, Jiang M, Lin F, Xu S, Zhang A, Tan M (2008) Nitric oxide reduces hydrogen peroxide accumulation involved in water stress-induced subcellular anti-oxidant defense in maize plants. J Integr Plant Biol. 50:231-243.

Santos MP (2009) O óxido nítrico modula os sistemas primários de transporte de prótons e as enzimas antioxidantes durante o estresse salino em plantas mutantes e não mutantes em ácido abscísico. 2009. 138p. Tese. Universidade Estadual do Norte Fluminense Darcy Ribeiro.

Sanz L, Albertos P, Mateos I, Sánchez-Vicent I, Lechón T, Fernández-Marcos, M, Lorenzo O (2015) Nitric oxide (NO) and phytohormones crosstalk during early plant development. J Exp Bot. 66: 2857-2868.

Sarath G, Bethke PC, Jones R, Baird LM, Hou G, Mitchell RB (2006) Nitric oxide accelerates seed germination in warmseason grasses. Planta. 223: 1154-1164.

Sethy SK, Ghosh S (2013) Effect of heavy metals on germination of seeds. J Nat Sci Biol Med. 4: 272-275.

Silva AL, Pinheiro DT, Borges EEL, Silva LJ, DIAS DCFS (2018) Tolerância à salinidade em sementes de Senna macranthera (DC. Ex Collad.) HS Irwin \& Barneby com nitroprussiato de sódio (SNP) promovido pelo cianeto. $J$ Seed Sci. 40: 323-330.

Silva JBC, Nakagawa J (1995) Estudo de fórmulas para cálculo da velocidade de germinação. Informativo ABRATES. 5: 6269.

Simões MS, Madail RH, Barbosa S, Nogueira ML (2013) Padronização de bioensaios para detecção de compostos alelopáticos e toxicantes ambientais utilizando Alface. Biotemas. 26: 29-36.

Simontacchi M, García-Mata C, Bartoli CG, Santa-María GE, Lamattina L (2013) Nitric oxide as a key component in hormone-regulated processes. Plant Cell Rep. 32: 853-866.

Sun JL, Luo LQ (2014) A study on distribution and chemical speciation of lead in corn seed germination by synchrotron radiation $\mathrm{X}$-ray fluorescence and absorption near edge structure spectrometry. Chinese J Anal Chem. 42: 14471452.

Taiz L, Zeiger E, Moller IM, Murphy A (2016) Fisiologia e Desenvolvimento Vegetal. Artmed, 6a ed. Porto Alegre, Rio Grande do Sul. 2017.

Wang HH, Huang JJ, BI YR (2010) Nitrate reductasedependent nitric oxide production is involved in aluminum tolerance in red kidney bean roots. Plant Sci. 179: 281288.

Wang P, Sun X, Chang C, Feng F, Liang D, Cheg L, Ma F (2013) Delay in leaf senescence of Malus hupehensis by long-term melatonin application is associated with its regulation of metabolic status and protein degradation. J Pineal Res. 55: 424-434.

Ya'acov YL, Haramaty E (1996) The characterization and contrasting effects of the nitric oxide free radical in vegetative stress and senescence of Pisum sativum Linn. foliage. J Plant Physiol. 148: 258-263.

Yruela I (2009) Copper in plants: acquisition, transport and interactions. Funct Plant Biol. 36: 409-430.

Zhang H, LIA YH, HUA LY, Wangb SH, Zhang F.Q, HU KD (2008) Effects of exogenous nitric oxide donor on antioxidant metabolism in wheat leaves under aluminum stress. Russ J Plant Physl. 55: 469-474. 